erfassen. Die aufgeführten Beispiele haben gezeigt, dass man unter Umständen zu falschen Schlüssen gelangt, wenn man sich bei der Suche nach Lösungen auf Teilaspekte beschränkt. Eine allgemein gültige Lehrbuch-Produktionsstrategie wird es auch in der Zukunft kaum geben. In jedem einzelnen Fall wird man überlegen müssen, was die richtige Antwort in der speziellen Situation ist.

[1] Zins auf Anlagevermögen; über die Lebensdauer einer Anlage (kalkulatorische Abschreibungsdauer) ist im Mittel die Hälfte des Anschaffungswertes in der Anlage gebunden.

2] Es wird in 2 Schichten à 5 Tage/Woche gearbeitet.

[3] Jahreskosten.

[4] Personal muss für das ganze Jahr bezahlt werden (Flexibilität bedingt Halten von Reserven!).

[5] Nur Arbeitslager; gleichmässiger Abgang des Produktes wurde angenommen.

[6] Einsatz bedeutet strategisch gesehen Anschaffung!

\title{
MRPII Implementation in the Process Industry
}

\author{
Robert Russell*
}

The objective of my presentation is to describe to you our experience of a Manufacturing Resource Planning, (MRPII) Implementation within our Dyestuffs \& Chemicals manufacturing site. We saw this as an opportunity to integrate our approach, not only within the site, but also with our customers and suppliers. We also saw it as a natural progression, building on the successes of our Total Quality Management (TQM) Process which had already begun to challenge many of our traditional attitudes and assumptions.

My presentation will be in 3 main parts:

- The Project

- Our experiences, lessons and conclusions

- Our future expectations

But firstly, let me give a little background about how the Clayton Aniline Company $(C A C)$ fits into the Ciba-Geigy Group.

$C A C$ is a mono-divisional chemical manufacturing site acting as one of the major international supply points for the Ciba-Geigy Dyestuffs and Chemicals Division worldwide. The manufacturing is supported on site by other functions such as Research \& Development, and Engineering. Manufacturing demand is received from the Division Logistics Department in Basle and production of finished dyestuffs and some intermediates is shipped back to Basle for subsequent manufacture or distribution, by Logistics, to worldwide selling companies. There is therefore no sales and marketing at $C A C$.

We are a batch manufacturer with a mixture of street based and multi-purpose plant. We are based in the centre of Manchester, a major city in the northern part of England. The site has been manufacturing dyestuffs for over 100 years and had a traditional culture with many information levels.

\section{The Project}

The goals of the project were clearly defined:

To support the $C A C$ strategic objectives of improving:

- Delivery reliability

- Manufacturing flexibility

- Cost effectiveness

and support, in the longer term, moves towards a J.I.T. philosophy.

The original concept was of a modernisation of the manufacturing support computer systems, but this was rapidly extended to a fundamental review and challenge to the traditional organisation, responsibilities and, in particular, performance measurements. This wider concept of integration was building on the review of roles and responsibilities which had been initiated by the TQM education. The importance of an integrated approach to performance measurement was rapidly appreciated, and forms a continuing theme throughout this presentation.

The concept of integration as a collective responsibility of the people working in the business and covering areas of:

- Customer/Supplier Relationships

- Business Goals and Targets

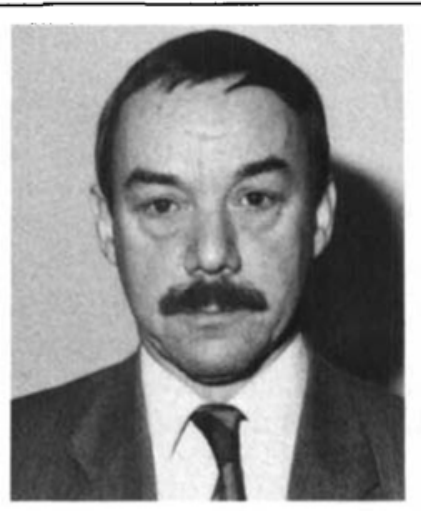

Bob Russell was born in England and gained a degree in Electronic Engineering in 1966. Following this, he worked for a number of U.K. Electronics companies and was involved in the development of aircraft communications equipment and training simulators for the military services. In $1973 \mathrm{hc}$ qualified as a Chartered Accountant gaining general finance and administrative experience through the audit of a number of U.K. multi-national companies. Joining Ciba-Geigy in 1974, he gained further Systems Analysis and software development experience through his involvement in the development and implementation of U.K. Group Finance Systems. In 1985 he moved to his current position, as Director of Finance with The Clayton Aniline Company, a dyestuffs manufacturing Company within the Ciba-Geigy Group. Here he was responsible for the implementation of the Company's MRPII Project. His interests relate to his broad technical and administrative experience, and cover the management of change through Total Quality Management initiatives, and particularly the impact of Performance Measurement on the roles and responsibilities of individuals and the need to integrate these measurements with the overall business strategy.

and supported by an emphasis on formality of process and information flow, was a major part of the education program. The need for a formal, integrated target setting and performance measurement system which drives the integration concept was also emphasised.

The MRPII methodology and project itself was divided into 5 main phases:

- Education

- Data reviews

* Correspondence: R. Russell

The Clayton Aniline Company

P.O.Box 2

Ashton New Road

Clayton

Manchester M114AP 
erfassen. Die aufgeführten Beispiele haben gezeigt, dass man unter Umständen zu falschen Schlüssen gelangt, wenn man sich bei der Suche nach Lösungen auf Teilaspekte beschränkt. Eine allgemein gültige Lehrbuch-Produktionsstrategie wird es auch in der Zukunft kaum geben. In jedem einzelnen Fall wird man überlegen müssen, was die richtige Antwort in der speziellen Situation ist.

[1] Zins auf Anlagevermögen; über die Lebensdauer einer Anlage (kalkulatorische Abschreibungsdauer) ist im Mittel die Hälfte des Anschaffungswertes in der Anlage gebunden.

2] Es wird in 2 Schichten à 5 Tage/Woche gearbeitet.

[3] Jahreskosten.

[4] Personal muss für das ganze Jahr bezahlt werden (Flexibilität bedingt Halten von Reserven!).

[5] Nur Arbeitslager; gleichmässiger Abgang des Produktes wurde angenommen.

[6] Einsatz bedeutet strategisch gesehen Anschaffung!

\title{
MRPII Implementation in the Process Industry
}

\author{
Robert Russell*
}

The objective of my presentation is to describe to you our experience of a Manufacturing Resource Planning, (MRPII) Implementation within our Dyestuffs \& Chemicals manufacturing site. We saw this as an opportunity to integrate our approach, not only within the site, but also with our customers and suppliers. We also saw it as a natural progression, building on the successes of our Total Quality Management (TQM) Process which had already begun to challenge many of our traditional attitudes and assumptions.

My presentation will be in 3 main parts:

- The Project

- Our experiences, lessons and conclusions

- Our future expectations

But firstly, let me give a little background about how the Clayton Aniline Company $(C A C)$ fits into the Ciba-Geigy Group.

$C A C$ is a mono-divisional chemical manufacturing site acting as one of the major international supply points for the Ciba-Geigy Dyestuffs and Chemicals Division worldwide. The manufacturing is supported on site by other functions such as Research \& Development, and Engineering. Manufacturing demand is received from the Division Logistics Department in Basle and production of finished dyestuffs and some intermediates is shipped back to Basle for subsequent manufacture or distribution, by Logistics, to worldwide selling companies. There is therefore no sales and marketing at $C A C$.

We are a batch manufacturer with a mixture of street based and multi-purpose plant. We are based in the centre of Manchester, a major city in the northern part of England. The site has been manufacturing dyestuffs for over 100 years and had a traditional culture with many information levels.

\section{The Project}

The goals of the project were clearly defined:

To support the $C A C$ strategic objectives of improving:

- Delivery reliability

- Manufacturing flexibility

- Cost effectiveness

and support, in the longer term, moves towards a J.I.T. philosophy.

The original concept was of a modernisation of the manufacturing support computer systems, but this was rapidly extended to a fundamental review and challenge to the traditional organisation, responsibilities and, in particular, performance measurements. This wider concept of integration was building on the review of roles and responsibilities which had been initiated by the TQM education. The importance of an integrated approach to performance measurement was rapidly appreciated, and forms a continuing theme throughout this presentation.

The concept of integration as a collective responsibility of the people working in the business and covering areas of:

- Customer/Supplier Relationships

- Business Goals and Targets

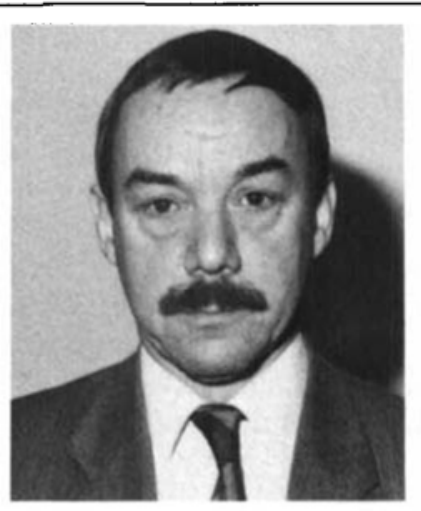

Bob Russell was born in England and gained a degree in Electronic Engineering in 1966. Following this, he worked for a number of U.K. Electronics companies and was involved in the development of aircraft communications equipment and training simulators for the military services. In $1973 \mathrm{hc}$ qualified as a Chartered Accountant gaining general finance and administrative experience through the audit of a number of U.K. multi-national companies. Joining Ciba-Geigy in 1974, he gained further Systems Analysis and software development experience through his involvement in the development and implementation of U.K. Group Finance Systems. In 1985 he moved to his current position, as Director of Finance with The Clayton Aniline Company, a dyestuffs manufacturing Company within the Ciba-Geigy Group. Here he was responsible for the implementation of the Company's MRPII Project. His interests relate to his broad technical and administrative experience, and cover the management of change through Total Quality Management initiatives, and particularly the impact of Performance Measurement on the roles and responsibilities of individuals and the need to integrate these measurements with the overall business strategy.

and supported by an emphasis on formality of process and information flow, was a major part of the education program. The need for a formal, integrated target setting and performance measurement system which drives the integration concept was also emphasised.

The MRPII methodology and project itself was divided into 5 main phases:

- Education

- Data reviews

* Correspondence: R. Russell

The Clayton Aniline Company

P.O.Box 2

Ashton New Road

Clayton

Manchester M114AP 
- Information Systems Implementation

- Integrated Performance Measurement

- Technological Integration

In terms of status today, I would say we are currently in the middle of the Performance Measurement phase.

\section{Education}

We were fortunate in this area to have the experience of another UK Ciba-Geigy site, who had also been through an MRPII implementation. Their message was a simple one:

\section{You can never educate enough!}

We therefore sent all our senior management, including board members, to external MRPII courses. We also sent senior plant supervision and union representatives to ensure the maximum commitment from these key plant personnel. The remainder of the workforce attended internal education sessions supported by a poster campaign, education booklets and an in-house developed video.

The aim of this major education exercise was to ensure maximum understanding of the principles and generate commitment and motivation.

The main points I would stress are:

- Keep the messages consistent for all the people

- Get the key people off-site so that they can mix with their counterparts in other businesses. This is the best way of challenging the 'we are unique' problem.

What are the key points contained in the education? They can be summarised by saying that we are talking about: 'A formal system for Manufacturing Planning and Control'. And by 'system', I mean all the ways in which people and information systems work together.

This formal system covers all the principles and procedures from the development of an overall Business Plan to meet the Customers' requirements, through to the detailed recording of manufacturing and supply activity, together with a regular, formal feedback of deviations from plan to ensure that all the information on which decisions are taken is consistent and up-todate.

The overall Business Plan should provide the basis for a shorter term Operational Plan which contains the Master Production Schedule. This is a statement of the strategy which Manufacturing should follow in order to meet customer requirements.

The next step is to test this strategy against existing capacity constraints, by Capacity Planning. If the strategy is not feasible, changes must be made to the Plan until it is feasible.

It is this stage which some traditional manufacturing approaches find most difficult, and it was on this point that the edu- cation concentrated. It was also the area where most discussion took place when formalising the operating principles and procedures, in particular in relation to our 'customer', the central Logistics Department.

The importance of accurate data was continually stressed, including a belief that data can be $100 \%$ accurate, if people understand why it is important, and take a professional pride in their job.

In summary, the MRPII message emphasised the need for:

Good Information

- accurate

- up to date all the time

Realistic assumptions and plans

Targets that make sense and are achievable Accepted measurements of what we do

Clear warnings of problems - in advance

Personal Responsibility

Working to Agreed Procedures

Everyone Involved

To Fulfil the Customers' Requirements

It answered the question 'What can I do?'

- Believe that the figures are important

- Record what I do - accurately

- Accept realistic targets - and try to meet them

Promise what I can do so that I can do what I promise ON TIME

And the question 'How can we achieve this?':

Agree with me:

- What my responsibilities are

- What my targets are

- How my actions contribute to the goals of the business

Measure me:

- On what I understand

- On what I can affect

- And tell me how well I am doing OFTEN

\section{Data Review}

As I have mentioned, the importance of data accuracy was a major part of the education process. We therefore carried out a review of the existing state of our manufacturing support data, in the areas of:

- Planning \& Control

- Inventories

- Bills of Materials

- Routings \& Work Centres

- Performance Measurements

We found a number of areas where the accuracy of data was very high:

- Material Process Data

- Technical Manufacturing Data

- Process Safety \& Ecology Data

This reflects the emphasis placed by Ciba-Geigy on the importance of process safety and ecological and environmental matters.
However, there were areas where this level of accuracy had not traditionally been regarded as top priority. These included:

\section{- Planning \& Capacity Data}

- Costing \& Accounting Data

In addition, the existing performance measurements were not totally consistent and integrated with the overall business goals and strategies.

The discussion which resulted from these findings provided a major challenge to the existing culture and to relationships, both between departments and with our 'customer' in the Division. Much further work is needed to improve accuracy further in these areas.

\section{Computer Systems Information}

An American software package called BPCS was chosen as providing a good basis for our requirements. Like all MRPII packages, however, it was engineering assembly biased and required significant inhouse enhancement to meet process industry needs. These centred on the following areas:

- Detailed container handling and lot traceability

- The concept of 'strength' or 'potency' of a dyestuff

- Campaign Planning

In addition, changes were required to meet the standards laid down by CibaGeigy for its internal product costing.

The system was implemented site-wide with access to up-to-date information and local responsibility for data accuracy. Data became much more visible.

In some cases, this visibility and local responsibility was a painful process and in addition the volume of data was a shock.

\section{Integrated Performance Measurement}

Having accepted the need to develop an integrated approach to performance measurement, the following principles were agreed:

- Agreement on the goals of the business

- Agreement on responsibilities

- Emphasis on performance to a schedule, rather than to fixed periodic targets

- Agreement on the level of aggregation of the data

We are still developing this structure and much further work is needed.

\section{Experiences, Lessons and Conclusions}

Much progress has been made and the benefits have already begun to appear:

- Greater accuracy of data leading to better decision making

- Clearer roles and responsibilities 
- Greater focus on areas which can lead to improvements in productivity

- More appropriate performance measurement

It is clear that a Total Quality scenario provides a good methodology for starting the 'unfreezing' of some traditional attitudes.

The major experiences and lessons can be summarised, firstly in general:

- The integrated approach causes major challenges to the whole Company culture

- Commitment and understanding take time

- Integrated information systems are vital

\section{BUT}

- People are the most vital

- Education is the key to success

- Many problems will arise

- They have not been caused by the new approach

- They have just been made visible

- Do not carry out any other major initiatives at the same time

- Get outside help early

- Do not over specify requirements

- Ensure maximum user access to the data

- Ensure agreement on performance reporting

- Data accuracy is a painful concept

- It challenges the past
- It causes difficulties when comparing past and future

- It raises issues of principle

- New ideas about planning means new ideas about product

costing and manufacturing accounting

- Educate everyone - with the same messages

- Ensure commitment from the top and understanding

- MRPII affects the whole organisation and highlights

the grey areas

Secondly, with regard to the software support, there were many lessons regarding the adaptation of a generic MRPII package to meet the needs of the process industry, but in general:

- Do not believe vendor promises - check it out

- Get outside technical help early - from people who have done it

- Develop in-house technical expertise in the software - do not rely on long term outside support

- Forget about vendor upgrades

- Do not forget about paper reports and summaries

\section{The Future}

We see major benefits still to come, but to achieve these we will need to continue the initiative, particularly in the areas of:
- Continuing Education

- Continuing improvement in data accuracy

- More emphasis still on formalisation of procedure and responsibilities

- Further development of Integrated Performance Measurement

Only then will technological integration realise its true potential, because it will be based on a sound foundation.

\section{Conclusion}

In this presentation I have outlined the major events and issues which we tackled. If the impression is gained that the people are the key, then I make no apology.

When people understand and are committed to realistic goals and work within clearly agreed procedures and to measurements of performance which support those goals, a good computer system can provide excellent, up-to-date decision support.

Without this formal people environment, the computer system is worse than useless, because it can give the illusion of accuracy, and lead to bad decisions.

The challenge of integrating manufacture is not so much about connecting technology together in the right way but more about connecting people together in the right way.

\section{Optimierung von Lagersystemen}

\section{Urs Schrader*}

\section{Einleitung / Abgrenzung des Themas}

Das Thema 'Optimierung von Lagersystemen' ist derart umfangreich und vielschichtig, dass im Rahmen dieses Referats nur einige ausgewählte Aspekte behandelt werden können. Die Auswahl wurde nach dem Motto getroffen:

'Welche Probleme werden zu diesem Thema von Führungskräften und Betrei-

\footnotetext{
* Korrespondenz: U. Schrader

Suter + Suter $A G$

Lautengartenstr. 23

$\mathrm{CH}-4010$ Basel
}

bern in der chemischen und pharmazeutischen Industrie am häufigsten diskutiert?'

Diese ausgewählten Problemkreise sind:

- Brauchen wir überhaupt noch Lager?

- Wie plant man ein Lagersystem? Gibt es neue Erkenntnisse?

- Was kostet ein Lagersystem?

- Wirtschaftlichkeit von Lagersystemen?

- Welche technischen Mittel stehen für die Rationalisierung der Logistik zur Verfügung? (z.B. Einsatz von Industrierobotern für die Kommissionierung)

- Was kostet 'Security and Safety' im Lagerbereich?

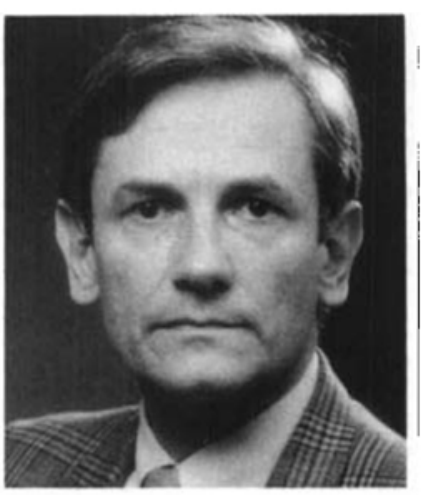

Urs Schrader: Geboren 1936. Gegenwärtige Stellung: Vizedirektor, Teilbereichsleiter Industrieberatung. Ausbildung: Ingenieurschule Burgdorf, Masch. Ing. HTL.

Berufliche Tätigkeit: 1959-1961 Bobst \& Fils SA, Lausanne, Planung einer neuen Produktionseinheit. 1961-1965 Alusuisse, Zürich, Planung verschiedener Produktionsbetriebe in Europa und USA. 1965-1967 Ramseier \& Jenzer AG, Bern, Chef der Konstruktionsabteilung. 1967-1971 Haldimann Management + Engineering Consultants, Zürich, Planung von Logistiksystemen. Seit 1971 Suter + Suter $A G$, Basel, Bereich Industrieberatung. 